Volume 14 Number 2 Pages $97-104,2020$

$\mathrm{Nationally}$ A c credited: No. 3/E/KPT/2019

http://jurnal.stie.asia.ac.id/index.php/jibeka

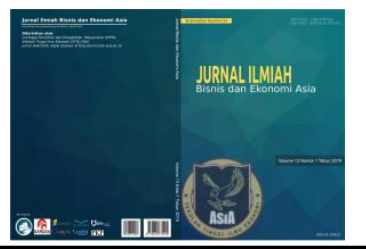

\title{
PEMANFAATAN SURAT KETERANGAN ASAL INDONESIA DALAM PENINGKATAN INVESTASI BERORIENTASI EKSPOR AUSTRALIA KE INDONESIA
}

\author{
Victor Tulus Pangapoi Sidabutar ${ }^{1^{*}}$ \\ ${ }^{1}$ Pusat Pendidikan dan Pelatihan Perdagangan, Kementerian Perdagangan Republik Indonesia, Indonesia
}

\section{INFO ARTIKEL}

DOI: $10.32812 /$ jibeka.v14i2.152

ISSN-P: 0126-1258

ISSN-E: 2620-875X

Keywords: Certificate of Origin, Export, Trade Agreement

\begin{abstract}
Indonesia has signed a trade agreement with Australia and hoped that this agreement can benefit both parties in facing global free trade. Indonesia is not Australia's main trading partner currently and Indonesia's exports to Australia tend to decline in recent years. Indonesia can take advantage of Australia's export market which is experiencing an increase in the value of exports which has risen faster than import prices which has affected the growth of the Australian economy. Indonesia can utilize the export market, especially markets that have trade agreements with Indonesia in order to indirectly increase Indonesian exports by utilizing the issuance of Certificates of Origin from Indonesia as partners of producers of Australian export products. The abundance of natural resources and labor in Indonesia is expected to attract the interest of Australia to invest in Indonesia to build an industry that aims to produce goods for the needs of the country's export market demand and for Indonesia to increase the entry of foreign direct investment to Indonesia.
\end{abstract}

\section{ABSTRAK}

Indonesia saat ini telah menandatangani perjanjian perdagangan dengan Australia dan diharapkan perjanjian ini dapat menguntungkan kedua belah pihak dalam menghadapi perdagangan bebas global. Indonesia saat ini bukanlah merupakan mitra dagang utama dari Australia bahkan ekspor Indonesia ke Australia cenderung mengalami penurunan dalam beberapa tahun terakhir. Indonesia dapat memanfaatkan pasar ekspor Australia yang sedang mengalami peningkatan nilai ekspor yang meningkat lebih cepat daripada harga impor yang berimbas dengan bertumbuhnya perekonomian Australia. Indonesia dapat memanfaatkan pasar ekspor tersebut terutama pasar yang memiliki perjanjian dagang juga dengan Indonesia dalam rangka meningkatkan ekspor Indonesia secara tidak langsung dengan memanfaatkan penerbitan Surat Keterangan Asal dari Indonesia sebagai mitra produsen dari produk ekspor Australia. Melimpahnya Sumber Daya Alam dan tenaga kerja di Indonesia diharapkan dapat menarik minat Australia untuk berinvestasi di Indonesia untuk membangun industri yang bertujuan untuk memproduksi barang untuk kebutuhan permintaan pasar ekspor negaranya dan bagi Indonesia dapat meningkatkan masuknya investasi asing ke dalam negeri Indonesia.

Kata Kunci: Surat Keterangan Asal,

Ekspor, Perjanjian Dagang 


\section{Pendahuluan}

Rencana Strategis Kementerian Perdagangan Tahun 2015 - 2019 (2015) salah satunya adalah memperluas pangsa pasar ekspor di pasar prospektif dan hub perdagangan Internasional. Indonesia saat ini terus melakukan negosiasi dan kesepakatan multilateral, regional dan bilateral dalam upaya untuk mengimbangi dinamika perekonomian dunia yang semakin cepat yang telah mengubah peta perdagangan dunia. Salah satu forum bilateral yang penting yang telah ditandatangani pada tanggal 4 Maret 2019 adalah Perjanjian Kerjasama Ekonomi Komprehensif antara Indonesia dengan Australia (IA-CEPA). IA-CEPA diharapkan menciptakan kerangka kerja bagi Australia dan Indonesia untuk membuka potensi luas dari kemitraan ekonomi bilateral, memupuk kerja sama ekonomi antara bisnis, masyarakat dan individu.

Australia adalah pasar terbuka dengan pembatasan minimal pada impor barang dan jasa. Keterbukaan yang dijalani saat ini telah meningkatkan produktivitas, merangsang pertumbuhan ekonomi yang lebih fleksibel dan dinamis. Australia memainkan peran aktif dalam WTO, APEC, G20, dan forum perdagangan lainnya. Perjanjian perdagangan bebas Australia (FTA) dengan Tiongkok mulai berlaku pada tahun 2015, menambah FTA yang ada sebelumnya dengan Republik Korea, Jepang, Chili, Malaysia, Selandia Baru, Singapura, Thailand, dan AS, dan FTA regional dengan ASEAN dan New Selandia Baru. Australia terus menegosiasikan perjanjian bilateral dengan Indonesia, serta perjanjian yang lebih besar dengan negara-negara tetangga Pasifik dan negara-negara Dewan Kerjasama Teluk, dan Kemitraan Ekonomi Komprehensif Regional yang mencakup seluruh Asia yang mencakup 10 negara ASEAN dan China, Jepang, Korea, Selandia Baru, dan India.

\section{Metode Penelitian}

Permasalahan yang akan dipecahkan pada kajian ini adalah dengan menggunakan metodologi penelitian berdasarkan teori Porter's Diamond (Porter 1990) yang dapat digunakan untuk mengidentifikasi dan menganalisa pengaruh kerjasama perdagangan Indonesia - Australia terhadap perkembangan perdagangan kedepannya (Gambar 1) didasarkan pada 4 hal, yaitu: (1) Kondisi permintaan; (2) Faktor Kondisi; (3) Strategi perusahaan, kestrukturan dan persaingan; (4) Industri terkait dan pendukungnya. Untuk itu, digunakan juga data sekunder mengenai perdagangan seperti perjanjian dagang, mitra dagang dari kedua negara.

\section{Gambar 1. Analisis Pengaruh Kerjasama Perdagangan antara Indonesia - Australia}

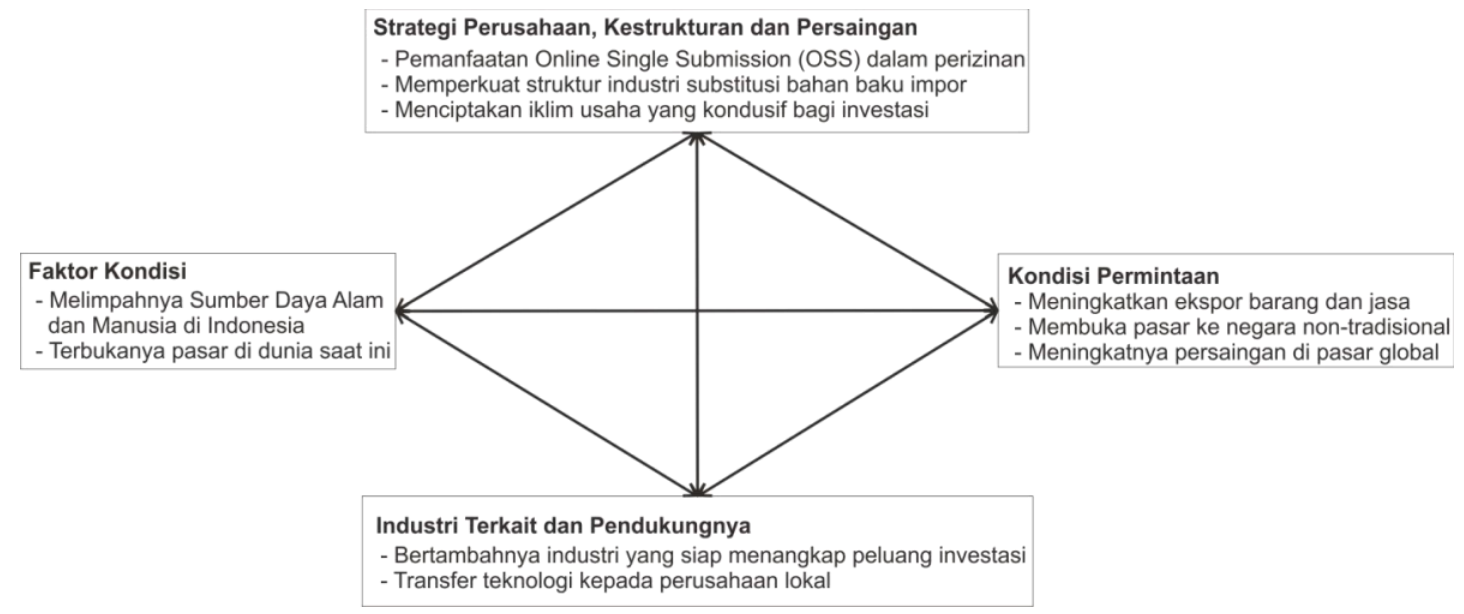

Sumber: Peneliti, 2020 


\section{Hasil Penelitian dan Pembahasan}

\section{A. Profil Perdagangan Negara Australia}

Berdasarkan data dari export.gov (2019), selama hampir dua dekade hingga tahun 2017, Australia telah mendapat manfaat dari lonjakan dramatis dalam hal perdagangannya dimana nilai ekspor meningkat lebih cepat daripada harga impor yang mengakibatkan perekonomian mengalami pertumbuhan yang berkelanjutan, pengangguran yang rendah, inflasi yang terkendali, utang publik yang sangat rendah, dan sistem keuangan yang kuat dan stabil. Pada 2018, Australia menghadapi berbagai hambatan pertumbuhan, terutama didorong oleh jatuhnya secara tajam harga global komoditas ekspor utama. Permintaan akan sumber daya dan energi dari Asia dan khususnya Cina tumbuh pada kecepatan yang lebih lambat dan penurunan tajam terjadi pada harga ekspor telah berdampak pada pertumbuhan Australia.

Mitra ekspor dari Australia (www.cia.gov) adalah (1) Tiongkok (33,5\%); (2) Jepang (14,6\%); (3) Republik Korea (6,6\%); (4) India (5\%); (5) Hong Kong (4\%), sedangkan mitra impor dari Australia (www.cia.gov) adalah (1) Tiongkok (22,9\%); (2) Amerika Serikat $(10,8 \%)$; (3) Jepang (7,5\%); (4) Thailand (5,1\%); (5) Jerman (4,9\%); (6) Republik Korea $(4,5 \%)$. Indonesia adalah pasar produk ekspor yang berkembang bagi Australia dan merupakan mitra dagang terbesar ke-13 (dfat.gov.au). Berdasarkan data dari trademap.org (2019), pertumbuhan ekspor produk dari Australia meningkat 3\% per tahunnya antara tahun 2014 hingga 2018 dimana pasar Indonesia merupakan 2\% dari total ekspor Australia. Sedangkan ekspor produk Indonesia ke Australia menunjukkan penurunan $-14 \%$ per tahunnya pada rentang waktu 2014 hingga 2018 dengan 2\% dari ekspor keseluruhan Indonesia. Pada 2017-18, total perdagangan barang dan jasa antara Australia-Indonesia bernilai USD 16,8 miliar, menjadikan Indonesia mitra dagang terbesar ke-13 dari Australia. IA-CEPA akan memberi peluang bisnis Australia dan Indonesia untuk memperluas dan mendiversifikasi kemitraan ekonomi ini. Selain mengurangi hambatan non-tarif untuk perdagangan dan menyederhanakan dokumen, IA-CEPA akan memungkinkan 99\% ekspor barang Australia untuk masuk ke Indonesia bebas bea atau dengan pengaturan preferensi yang ditingkatkan secara signifikan. Semua ekspor barang Indonesia akan masuk ke Australia bebas bea.

IA-CEPA diharapkan akan meningkatkan kondisi untuk pemasok jasa dan iklim untuk investasi dua arah. Pemasok dan investor jasa Australia akan memiliki kepastian yang lebih besar untuk masuk dan beroperasi di pasar Indonesia, membantu memfasilitasi lebih banyak investasi Australia di Indonesia. Ini akan menciptakan lebih banyak peluang bagi warga Australia untuk membantu memenuhi kebutuhan investasi Indonesia yang terus meningkat dan untuk penyediaan layanan kelas dunia di pasarnya. Kerjasama ini akan menghilangkan banyak tarif penghalang dan juga memberikan kesempatan anak muda Indonesia untuk memperoleh Visa kerja ke Australia.

\section{B. Perkembangan Perdagangan dan Investasi Australia di Indonesia}

Berdasarkan data dari BPS (2019), ekspor Indonesia pada Januari - Maret 2019 mencapai volume 161.609 ,ton dengan nilai USD 40.605,7 juta, yang terdiri dari USD $3.485,5$ juta hasil ekspor minyak bumi dan gas dan USD 37.120,2 juta hasil ekspor komoditi nonmigas. Dibandingkan periode yang sama tahun 2018, nilai ekspor tahun 2019 turun USD $3.613,6$ juta karena adanya penurunan ekspor migas senilai USD 502,1 juta dan dari kelompok non migas menurun USD 3.111,5 juta. 
Tabel 1. Perkembangan Ekspor Migas \& Non Migas Indonesia Menurut Negara Tujuan, Maret 2018 dan Maret 2019 (dalam Juta USD)

\begin{tabular}{|c|c|c|c|c|c|c|}
\hline \multirow{2}{*}{$\begin{array}{c}\text { Kawasan } \\
\text { Negara } \\
\text { Tujuan } \\
\text { Ekspor }\end{array}$} & \multicolumn{3}{|c|}{ Migas } & \multicolumn{3}{|c|}{ Nonmigas } \\
\hline & Maret 2018 & Maret 2019 & $\begin{array}{c}\text { Perubahan } \\
\text { (\%) }\end{array}$ & Maret 2018 & Maret 2019 & $\begin{array}{c}\text { Perubahan } \\
\text { (\%) }\end{array}$ \\
\hline Asia Timur & 679,7 & 547,2 & $-19,49$ & $4.901,6$ & $4.310,9$ & $-12,05$ \\
\hline Jepang & 212,6 & 152,2 & $-28,41$ & $1.430,0$ & $1.173,5$ & $-17,94$ \\
\hline Tiongkok & 147,3 & 221,8 & 43,79 & $2.357,5$ & $1.973,2$ & $-16,30$ \\
\hline $\begin{array}{l}\text { Asia } \\
\text { Selatan \& } \\
\text { Tenggara }\end{array}$ & 399,6 & 542,4 & 35,74 & $4.447,1$ & $4.480,4$ & 0,75 \\
\hline Thailand & 96,4 & 86,0 & $-10,79$ & 502,3 & 473,0 & $-5,8$ \\
\hline Singapura & 173,8 & 352,4 & 102,76 & 780,9 & 691,0 & $-11,51$ \\
\hline Filipina & 0,1 & 2,1 & $2.000,00$ & 535,8 & 615,6 & 14,89 \\
\hline Malaysia & 100,8 & 68,5 & $-32,04$ & 648,9 & 628,9 & $-3,08$ \\
\hline Asia Barat & 0,4 & 0,2 & $-50,00$ & 526,5 & 473,9 & $-9,99$ \\
\hline Afrika & 0,0 & 0,0 & - & 423,0 & 388,8 & $-8,09$ \\
\hline $\begin{array}{l}\text { Australia \& } \\
\text { Oceania }\end{array}$ & 100,1 & 12,3 & $-87,71$ & 251,8 & 199,4 & $-20,81$ \\
\hline $\begin{array}{l}\text { Amerika } \\
\text { Utara }\end{array}$ & 66,9 & 38,3 & $-42,84$ & $1.668,9$ & $1.445,2$ & $-13,40$ \\
\hline $\begin{array}{l}\text { Amerika } \\
\text { Serikat }\end{array}$ & 66,9 & 38,3 & $-42,84$ & 1590,6 & 1380,3 & $-13,22$ \\
\hline $\begin{array}{l}\text { Amerika } \\
\text { Tengah \& } \\
\text { Selatan }\end{array}$ & 0,0 & 0,0 & - & 303,9 & 286,8 & $-5,59$ \\
\hline $\begin{array}{l}\text { Eropa } \\
\text { Barat }\end{array}$ & 9,4 & 0,1 & $-98,94$ & $1.498,6$ & $1.119,5$ & $-25,30$ \\
\hline $\begin{array}{l}\text { Eropa } \\
\text { Timur }\end{array}$ & 0,0 & 0,0 & - & 233,1 & 276,4 & 18,58 \\
\hline $\begin{array}{l}\text { Total } \\
\text { Ekspor }\end{array}$ & $1.256,2$ & $1.140,5$ & $-9,21$ & $14.254,5$ & $12.981,4$ & $-8,93$ \\
\hline
\end{tabular}

Sumber: Buletin Statistik Perdagangan Luar Negeri Menurut Kelompok Komoditi dan Negara (2019)

Terdapat lima produk utama yang diimpor Australia dari Indonesia berdasarkan total impor mengacu pada data trademap.org (2018) adalah (1) tembakau dan pengganti tembakau pabrikan (29\%); (2) kayu dan barang dari kayu; arang kayu (13\%); (3) alat-alat musik; bagian dan aksesori dari barang tersebut (13\%); (4) garam; belerang; bumi dan batu; bahan plesteran, kapur dan semen (11\%); (5) bulu dan bulu olahan dan barang yang terbuat dari bulu atau bulu binatang; bunga buatan; artikel bunga (8\%); Manufaktur dari jerami, dari esparto atau dari bahan anyaman lainnya; keranjang dan anyaman (8\%); Olahan kakao dan kakao (8\%). Bulu dan bulu olahan merupakan salah satu produk yang sedang meningkat permintaannya dimana terjadi peningkatan permintaan setiap tahunnya dari tahun 2014 hingga 2018 sebesar 16\% dimana Indonesia dapat mengambil 8\% dari total impor Australia ditahun 2018. Berdasarkan negara tujuan ekspor, neraca perdagangan Indonesia ke Australia tidak sebagus sebaliknya. Neraca perdagangan Indonesia ke Australia mengalami kecenderungan menurun pada rentang 2016 hingga 2018, yang dapat dilihat pada Gambar 2 , sebaliknya Australia menikmati peningkatan ekspor produknya ke Indonesia pada rentang tahun yang sama. 


\section{Gambar 2. Perbandingan Neraca Perdagangan Indonesia dan Australia}

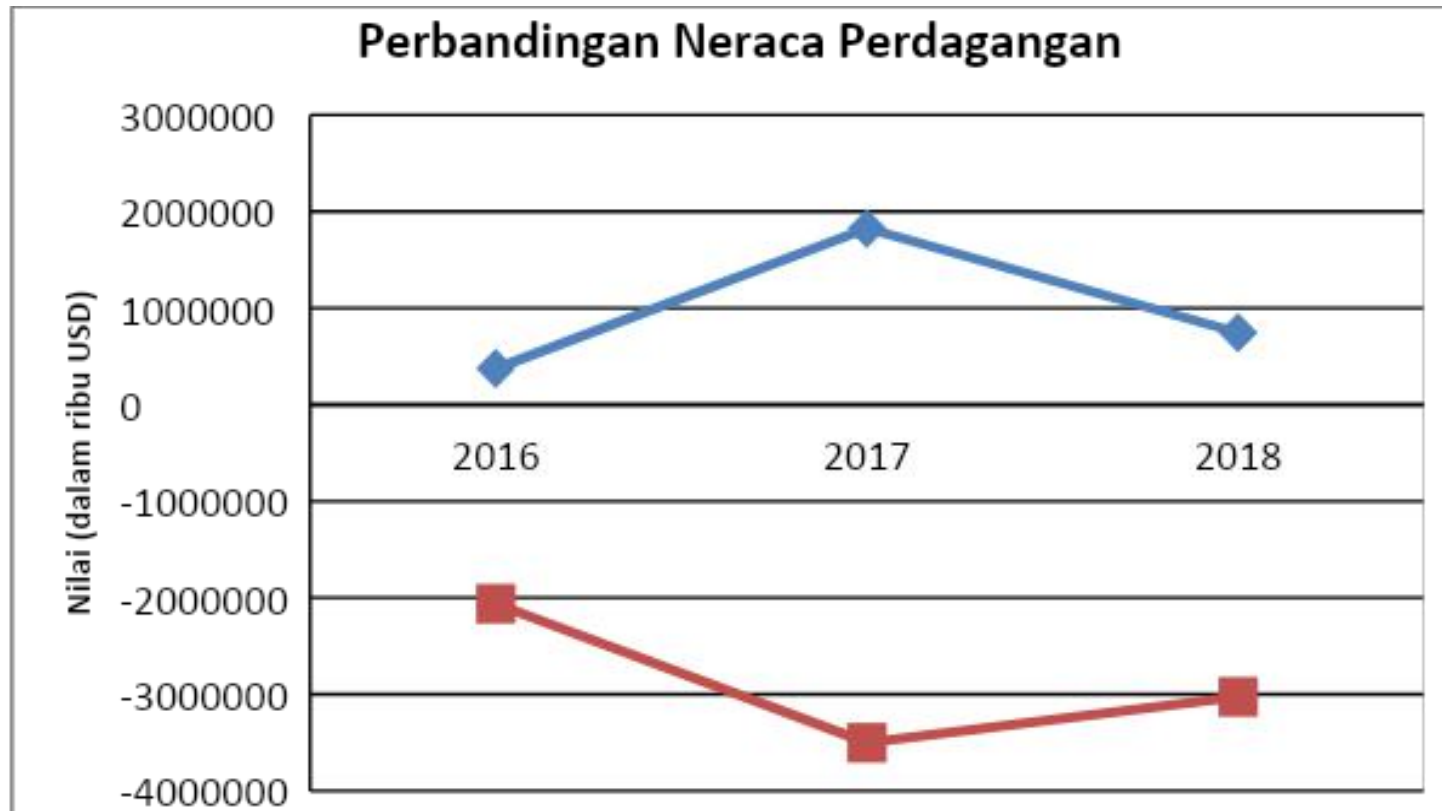

Sumber: diolah dari trademap.org, 2019

\section{Strategi Peningkatan Ekspor Indonesia}

Berdasarkan data realisasi investasi di Indonesia yang dikeluarkan oleh Badan Koordinasi Penanaman Modal (BKPM) untuk triwulan pertama (Januari-Maret) tahun 2017, Australia berada di peringkat ke-12 dengan total investasi sebesar USD 146,69 juta dengan 158 proyek dan pada triwulan kedua kedua (periode April-Juni) di tahun 2017, Australia berada di peringkat ke-18 dengan total investasi sebesar USD 59,3 juta dengan 366 proyek. Investasi Australia di Indonesia saat ini yang paling banyak menyerap tenaga kerja serta dengan tingkat penjualan tertinggi berdasarkan data dari investmentmap.org (2017) terbanyak pada sektor penambangan dan penggalian.

Indonesia dapat menarik minat investasi asing Australia lebih lagi dengan memanfaatkan Sumber Daya Alam dan Manusia Indonesia yang melimpah untuk membuat industri kebutuhan mereka di Indonesia. 5 besar impor Australia yang meningkat permintaannya dari tahun 2014 hingga 2018 berdasarkan data trademap.org (2019) adalah (1) pesawat terbang, pesawat ruang angkasa, dan bagian-bagiannya (57\%); (2) bahan anyaman sayuran; produk nabati tidak dirinci atau termasuk dalam pos lainnya (33\%); (3) bijih, terak dan abu (19\%); (4) bulu dan bulu olahan dan barang yang terbuat dari bulu atau bulu binatang; bunga buatan; artikel bunga (16\%); (5) timah dan artikelnya (15\%).

Kesemuanya ini dapat dipenuhi oleh industri Indonesia baik industri skala kecil hingga besar, sedangkan untuk keperluan ekspor Australia ke dunia, mereka dapat investasi industri berorientasi ekspor mereka di Indonesia. Indonesia dapat menggunakan Operational Certification Procedures (OCP) dimana Indonesia dapat memanfaatkan prosedur penerbitan dan verifikasi Surat Keterangan Asal (SKA) dan hal-hal administrasi terkait lainnya yang harus dipatuhi oleh masing-masing Pihak FTA pada negara yang menjadi importir mitra Australia.

Strategi yang diterapkan dapat dengan cara menerapkan:

\section{Strategi Faktur Negara Ketiga (Third Country Invoicing)}

Faktur Negara Ketiga ( $\mathrm{TCl}$ ) mengacu pada pengaturan, di mana faktur yang menyertai Preferensial Surat Keterangan Asal (SKA) dan digunakan untuk pengambilan barang di 
pihak pengimpor, tidak dikeluarkan dari pihak pengekspor tetapi dari negara lain yang mungkin tidak perlu berada dalam FTA yang sama dengan pengimpor. Menurut Lim (2015), SKA dapat diterbitkan oleh negara ketiga yang bertindak sebagai agen penjualan dimana pihak ini terlibat dalam penentuan harga dari produk. Dalam beberapa FTA, TCI biasanya disebut sebagai Faktur Pihak Ketiga.

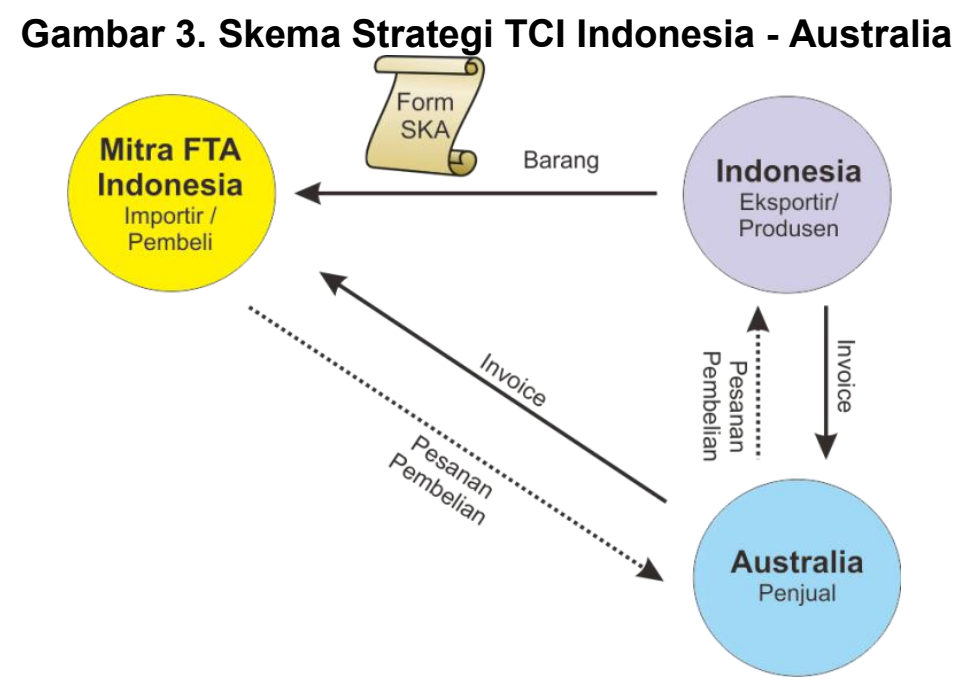

Sumber: Peneliti, 2020

Barang yang berasal dan diekspor dari Indonesia ke negara mitra FTA Indonesia dengan SKA Form preferensial tertentu. Namun, faktur yang ditagih ke mitra FTA Indonesia dikeluarkan dari Australia. Negara importir tersebut masih dapat menerima Formulir SKA tersebut dan memberikan akses preferensi untuk barang yang ditunjukkan dalam Formulir SKA meskipun faktur tidak dikeluarkan dari Indonesia tetapi negara lain yang tidak memiliki FTA dengan negara importir. Dalam keadaan seperti itu, pemohon Preferential SKA harus menunjukkan rincian faktur yang dikeluarkan dari negara ketiga di SKA Preferential.

\section{Preferensial Back-to-Back (B2B) SKA}

Menurut Lim (2015), preferensial back-to-back SKA dikeluarkan oleh otoritas penerbit di negara perantara Perjanjian Perdagangan Bebas (FTA) untuk mengekspor kembali barang, berdasarkan pada Preferential SKA yang dikeluarkan oleh Pihak pengekspor pertama. Barang diijinkan untuk menjalani operasi seperti pembongkaran massal dan pengerjaan lain yang diperlukan untuk memfasilitasi transportasi tanpa kehilangan status asalnya.

Hal ini berlaku asalkan ada lebih dari dua pihak dalam FTA yang sama dan bahwa eksportir di pihak perantara dapat memenuhi semua persyaratan yang ditetapkan dalam FTA untuk memenuhi syarat untuk aplikasi SKA Preferensial back-to-back. Tetapi hal ini bergantung dari kesepakatan serta preferensi antara eksportir dan importir. Jika terdapat preferensi di dalam perjanjiannya yang menolak adanya transaksi perdagangan yang melibatkan pihak ketiga sebagai pemasok dan menginginkan penciptaan pasar perdagangan baru sehingga memotong jalur masuknya transaksi murni hanya antara eksportir dan importir, maka dalam penetapan Rules of Origin perlu di perhatikan apakah ada tidaknya re-ekspor kembali atau transshipment pada saat melakukan ekspor. 


\section{Gambar 4. Skema Strategi Penggunaan Preferensial Back-to-back SKA}

Sumber: Penulis, 2020

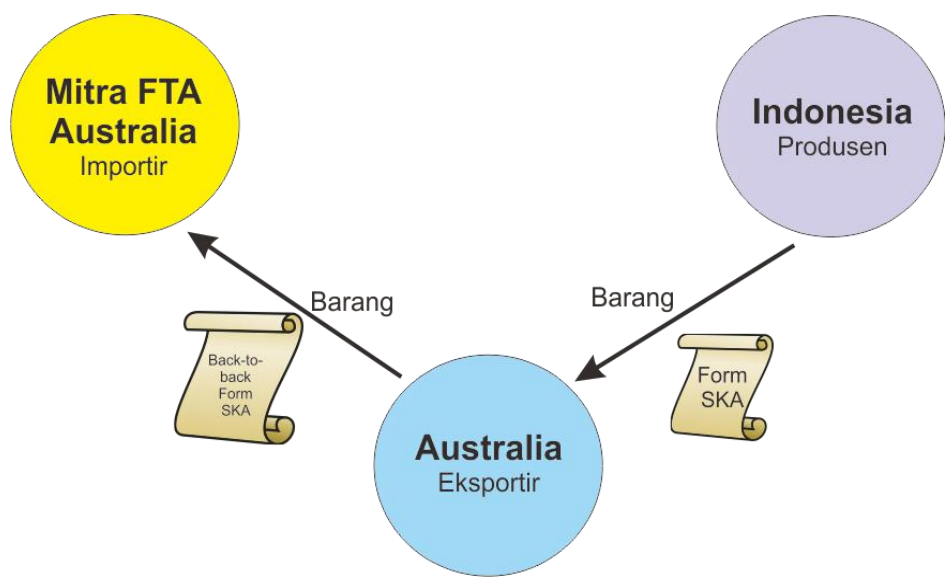

\section{IV.Kesimpulan}

Kerjasama Indonesia - Australia dapat dimanfaatkan Indonesia untuk meningkatkan masuknya investasi di bidang perindustrian berorientasi ekspor yang dapat membantu Australia dalam meningkatkan ekspor ke negara mitra dan non mitra. Indonesia dapat memanfaatkan preferensial SKA untuk memasuki pasar negara mitra FTA Indonesia yang selama ini belum secara maksimal dimanfaatkan Indonesia. Hal ini dapat meningkatkan citra produk Indonesia yang sebelumnya belum diterima di negara tersebut tetapi dengan bermitra dengan Australia maka produk produksi Indonesia dapat masuk dan dikenal di negara tersebut. Kedepannya dapat dilakukan penelitian untuk melihat pengaruh dari penggunaan $\mathrm{TCl}$ dan $\mathrm{B} 2 \mathrm{~B}$ bagi perusahaan industri manufaktur berskala menengah dan kecil untuk dapat meningkatkan daya saing industri kecil dan menengah dalam kerangka ekspor.

\section{Daftar Pustaka}

Crook, W. and Gordon, J. (2017). Rules of Origin: can the noodle bowl of trade agreements be untangled? Productivity Commission Staff Research Note, Canberra, May.

Porter, M.E. (1990). Competitive Advantage of Nations: With a New Introduction. The Free Press, New York.

Lim, H. and A. Choo (2015). 'The Use of Free Trade Agreements by Manufacturing',in Ing, L.Y. and S. Urata (eds.), The Use of FTAs in ASEAN: Survey-based Analysis. ERIA Research Project Report 2013-5, Jakarta: ERIA. pp.215-242

Rencana Strategis Kementerian Perdagangan Tahun 2015 - 2019 (2015). Peraturan Menteri Perdagangan Republik Indonesia No 27/M-DAG/PER/4/2015 Tentang Rencana Strategis Kementerian Perdagangan Tahun 2015 - 2019.

Online (2019). Sumber tentang kerjasama ekonomi Indonesia-Australia. Diunduh pada tanggal 18 Juni 2019 dari https://dfat.gov.au/trade/agreements/not-yet-inforce/iacepa/Pages/indonesia-australia-comprehensive-economic-partnershipagreement.aspx

Online (2019). Sumber tentang profil ekonomi negara Australia. Diunduh pada tanggal 18 Juni 2019 dari https://www.cia.gov/library/publications/resources/the-worldfactbook/geos/as.html 
Online (2019). Sumber tentang mitra dagang ekspor impor negara Australia. Diunduh pada tanggal 19 Juni 2019 dari https://www.export.gov/article?id=Australia-Market-Overview

Online (2019). Sumber tentang investasi asing yang masuk ke Indonesia. Diunduh pada tanggal $18 \quad$ Juni $2019 \quad$ dari https://www.bkpm.go.id/images/uploads/investasi_indonesia/file/2\%29_Paparan_Bahas a_Inggris_Press_Release_TW_II_dan_Jan_Juni_2017.pdf

Online (2019). Sumber tentang investasi asing yang masuk ke Indonesia pada triwulan pertama. Diunduh pada tanggal 18 Juni 2019 dari https://www.bkpm.go.id/images/uploads/investasi_indonesia/file/Paparan_Bahasa_Inggr is_TW_I_2017.pdf

Online (2019). Sumber tentang profil bisnis negara Australia. Diunduh pada tanggal 18 Juni 2019 http://www.doingbusiness.org/content/dam/doingBusiness/country/a/australia/AUS.pdf

Online (2019). Sumber tentang profil bisnis negara Indonesia. Diunduh pada tanggal 18 Juni 2019 dari http://www.doingbusiness.org/content/dam/doingBusiness/country/i/indonesia/IDN.pdf

Online (2019). Sumber tentang peta investasi dunia. Diunduh pada tanggal 18 Juni 2019 dari https://www.investmentmap.org/prioritySector_comp.aspx

Online (2019). Sumber tentang neraca perdagangan bilateral antara Indonesia dan Australia. Diunduh pada tanggal 18 Juni 2019 dari https://www.trademap.org/Bilateral.aspx?nvpm=1\%7c360\%7c\%7c036\%7c\%7cTOTAL\% 7c\%7c\%7c2\%7c1\%7c1\%7c2\%7c1\%7c1\%7c1\%7c1\%7c1 